\title{
Experimental investigation on Utilization of Polyester Fiber for Improved Properties of Concrete
}

\author{
Vaibhav Shirodkar ${ }^{1}$, Manasi Lolienkar $^{2}$ \\ Dept. of Civil Engineering, Girijabai sail institute of technology Karwar, Karnataka, India
}

\begin{abstract}
The present investigation was carried out to determine the split tensile strength and also the resistance to cracking by determining the flexural strength of plain concrete and polyester fiber reinforced concrete by using "Recron 3s", a polyester fiber by Reliance. This is aimed at increasing the tensile strength and flexural strength of concrete which weak in tension and only strong in compression. This is also aimed at increasing the ductility of concrete under tensile stresses. OPC 43 Grade Cement was used in this work and all the necessary testes on cement and aggregates were conducted. Various fiber percentages of $0.2 \%, 0.4 \%$, and $0.6 \%$ by weight of cement were tested for compressive strength, split tensile strength, and flexural strength. These mixes were then compared with a nominal mix with $0 \%$ fiber. A comparative analysis was carried out so as to obtain the percentage increase/decrease in strength due to the addition of fibers for all the above tests. It was observed that addition of fiber percentage of $0.4 \%$ gave the maximum strengths for all the three tests.
\end{abstract}

Keywords: Compressive Strength, Flexural Strength, Mix Proportion, Split Tensile Strengths, Water Cement ratio.

\section{Introduction}

"Polyester Fiber Reinforced Concrete" is relatively a new construction material developed through extensive research and development work during the last two decades. Polyester Reinforced Concrete is defined as composite material which consists of conventional concrete reinforced by randomly dispersed short length fibers of specific geometry, made of synthetic materials.

Plain cement concrete has very low tensile strength and causes formation of micro cracks in stressed and unstressed states of concrete. Also, it has a low strain at fracture and brittleness with less ductility especially in case of High Performance Concrete. Polyester Reinforced Concrete is the answer to modify these properties of Plain Concrete.

\section{Materials And Method}

Cement: In this experiment, 43 Grade Ordinary Portland Cement (OPC) with brand name JK Cement was used for all concrete mixes. The cement used was fresh and free from lumps and impurities. The testing of cement was done as per IS 8112:1989. The specific gravity of cement was found to be 3.15

Fine Aggregate: The sand used for the experimentation was locally procured and was confined to zone-II. The specific gravity of fine aggregate was found to be 2.67 . The fine aggregate used for all the specimens was complying with IS 383-1970.

Coarse Aggregate: The coarse aggregate used in this experimentation were $20 \mathrm{~mm}$ and $10 \mathrm{~mm}$ size and was confirming to IS 383-1970. The specific gravity was found to be 2.68 .

Water: The water used was clean and free from oils, salts and acids. Portable water available in the laboratory was used for casting all the specimens in this investigation. The quality of water was found to satisfy the requirements of IS 456-2000.

Fiber: In this experiment, "Recon $3 \mathrm{~s}$ " a $12 \mathrm{~mm}$ long virgin triangular monofilament polyester fiber manufactured by Reliance was used.

Mix Proportion: M20 Grade of concrete with the mix ratio (1:1.5:3) was adopted with and the water cement ratio was 0.3 . The fiber quantity in concrete was varied in percentages like $0 \%, 0.2 \%, 0.4 \%, 0.6 \%$ by weight of cement.

\subsection{Tests Conducted}

Compressive Strength Test: For the compressive strength test, the specimens of size 150 X150 X150mm were cast and tested on compressive testing machine of capacity 2000KN as per IS 516: 1959.

Split Tensile Strength of Concrete: For the tensile strength, the cylindrical specimens of size $150 \mathrm{~mm}$ diameter and $300 \mathrm{~mm}$ length were cast. Split tensile strength was obtained by testing the specimen on CTM of capacity 2000KN as per IS 5816: 1999. 
Flexural Strength of Concrete: For the flexural strength, the beam specimens of size $100 \times 100 \mathrm{X} 500 \mathrm{~mm}$ were cast. Two point loading was adopted on an effective span of $400 \mathrm{~mm}$ while testing the beam specimens as per IS 516: 1959.

Mix Proportion and Water Cement ratio: A constant mix proportion of 1: 1.5: 3 was used for all the samples tested. The water cement ratio adopted was 0.3 and was kept constant for all the mixes

\section{Indentations And Equations}

Where,

Compressive Strength $=$ L/A................... (1)

$\mathrm{L}=$ load

$\mathrm{A}=$ cross-sectional area

Split Tensile Strength of Concrete $=0.637 \mathrm{P} / \mathrm{DL}$

Where,

$\mathrm{P}=$ Failure load

$\mathrm{D}=$ Diameter of cylindrical specimen $(150 \mathrm{~mm})$

$\mathrm{L}=$ Length of the cylindrical specimen $(300 \mathrm{~mm})$

Where,

Flexural Strength or modulus of Rupture is given by $\mathrm{F}=\mathrm{PL} / \mathrm{bd}^{2}$ in $\mathrm{N} / \mathrm{mm}^{2}$

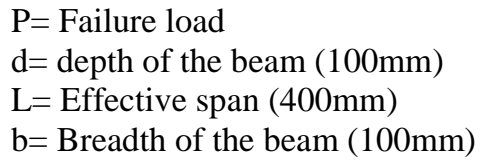

IV. Figures And Tables

Table 4.1 Comparison of strength for 7, 14 and 28 days

\begin{tabular}{|c|c|c|c|}
\hline \multirow[b]{2}{*}{$\%$ of fibers } & \multicolumn{3}{|c|}{ Compressive Strength in days } \\
\hline & 7 days & 14 days & 28 days \\
\hline $0 \%$ & 14.88 & 16.89 & 21.11 \\
\hline $0.20 \%$ & 16.44 & 20.22 & 23.78 \\
\hline $0.40 \%$ & 17.78 & 22 & 25.77 \\
\hline $0.60 \%$ & 16.11 & 19.33 & 24.22 \\
\hline & \multicolumn{3}{|c|}{ Flexural Strength in days } \\
\hline$\%$ of fibers & 7 days & 14 days & 28 days \\
\hline $0 \%$ & 3.49 & 5.17 & 8.63 \\
\hline $0.20 \%$ & 3.84 & 5.76 & 9.61 \\
\hline $0.40 \%$ & 4.39 & 6.63 & 10.98 \\
\hline $0.60 \%$ & 4.12 & 5.7 & 8.63 \\
\hline \multirow[b]{2}{*}{$\%$ of fibers } & \multicolumn{3}{|c|}{ Split Tensile Strength in days } \\
\hline & 7 days & 14 days & 28 days \\
\hline $0 \%$ & 0.848 & 1.484 & 2.20 \\
\hline $0.20 \%$ & 1.06 & 1.767 & 2.475 \\
\hline $0.40 \%$ & 1.41 & 1.979 & 2.820 \\
\hline $0.60 \%$ & 1.06 & 1.908 & 2.686 \\
\hline
\end{tabular}




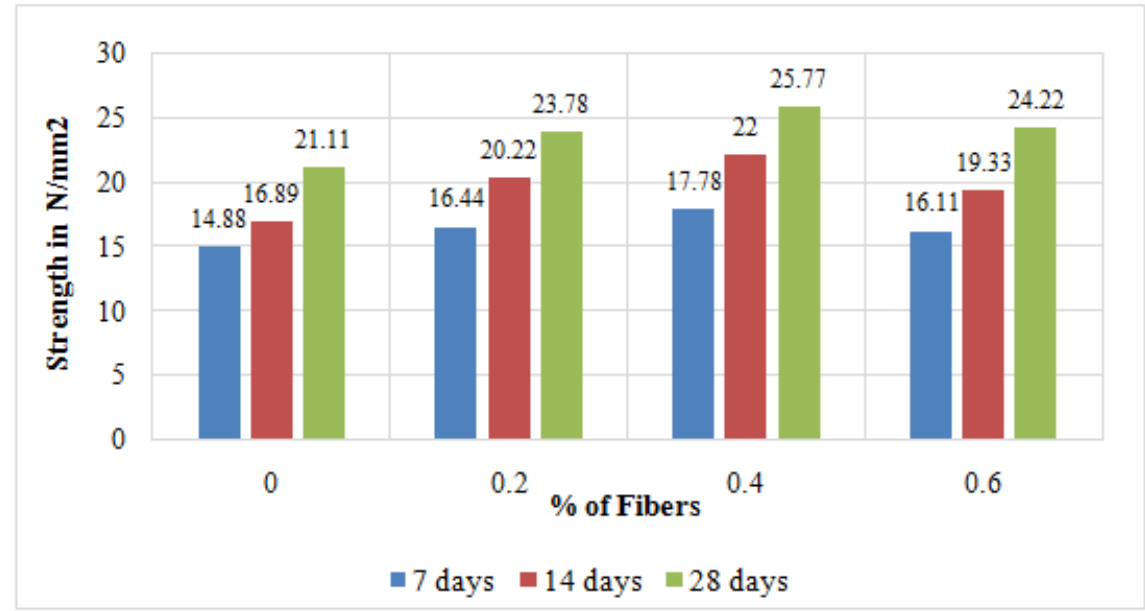

Fig 4.1 Comparison of Compressive strength for 7,14 and 28 days

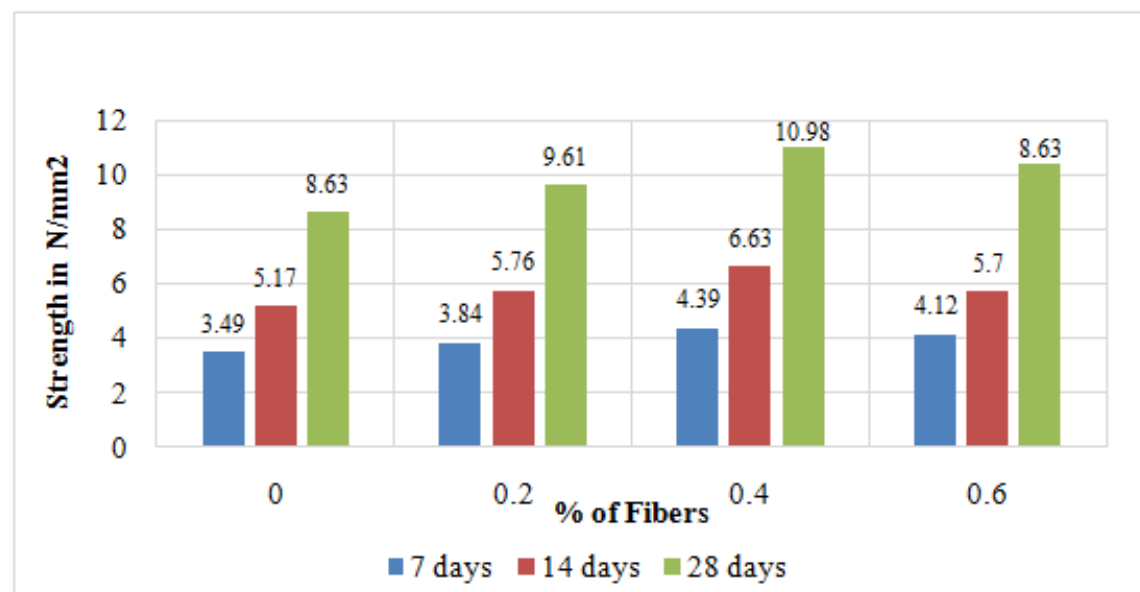

Fig 4.2 Comparison of Flexural Strength for 7, 14 and 28 days

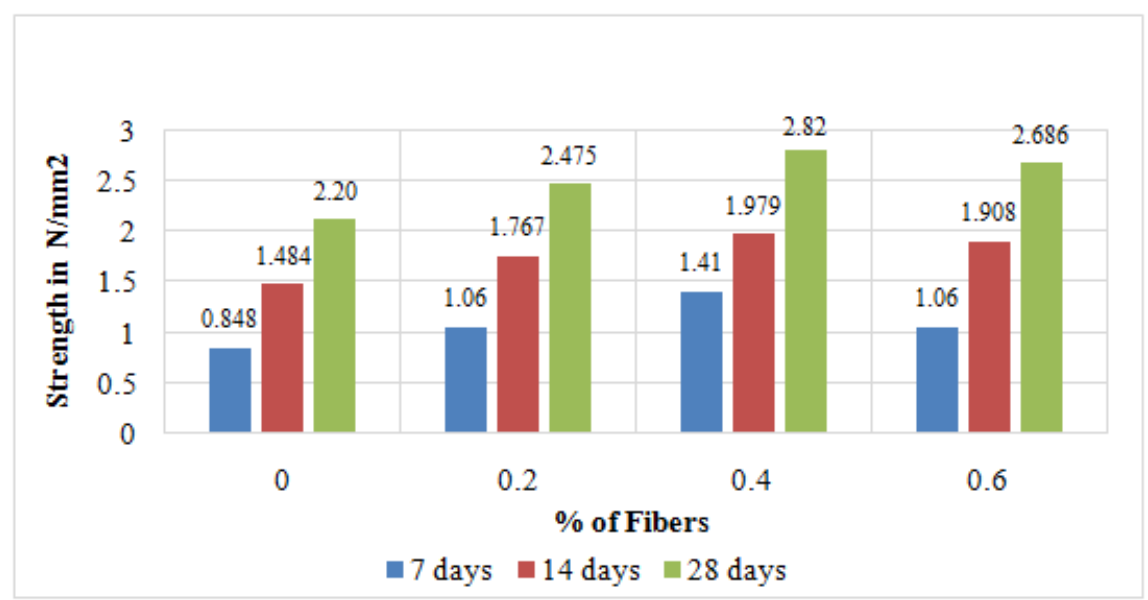

Fig 4.3 Comparison of Split Tensile Strength for 7, 14 and 28 days

\section{Conclusion}

1. The maximum compressive strength is obtained when the percentage of fiber added is $0.4 \%$; the maximum compressive strength being $25.77 \mathrm{~N} / \mathrm{mm} 2$.

2. The maximum flexural strength is obtained when the percentage of fiber added is $0.4 \%$; the maximum flexural strength being $10.98 \mathrm{~N} / \mathrm{mm} 2$.

3. The maximum split tensile strength is obtained when the percentage of fiber added is $0.4 \%$; the maximum split tensile strength being $2.82 \mathrm{~N} / \mathrm{mm} 2$. 
4. It is found that the compressive strength, flexural strength and split tensile strength is the highest at $0.4 \%$ addition of fibers and reduces when the percentage of fiber added exceeds beyond $0.4 \%$.

5. At $0.4 \%$ addition of fibers, the compressive strength is found to be increased by $22.07 \%$ Since the 28 days split tensile strength is found to be increased by $33.02 \%$, these fibers can be used as secondary replacement with steel. These fibers when used as secondary reinforcements can lead to considerable cost savings. At higher percentage of addition of fibers, due to less bonding of the fibers with the concrete mix results in lower strengths.

\section{Future Scope}

1. These fibers can be used as secondary reinforcements with steel due to its ductile properties.

2. This can have considerable savings in costs of steel.

3. This fiber reinforced concrete can be studied and tested for marine condition for construction of hydraulic structures.

4. The behavior of this concrete for pavement surfaces can be tested.

5. The fibers can be tested for secondary reinforcement with steel which could well reduce the quantity of steel used.

\section{Acknowledgements}

I would like to express my gratitude and sincere acknowledgment to my Dr. Suresh D. Mane, Principal, Girijabai sail institute of technology, karwar.He continuously helped with his valuable suggestions and encouragement during the entire project.

I am grateful to prof. Somashekar patil, Head of civil engineering department for providing me the necessary help and encouragement whenever needed which has resulted in the success of my project.

I would also like to thank all the staff member of our department, without whose constructive suggestion and valuable advice, the simple idea which has been borne by me, would not been able to blossom forth to give such a beautiful bloom.

Last but not the least; I am grateful to all my family member and friends for their direct and indirect constant moral support through the project.

\section{References}

[1]. (AFRREV) an International Multidisciplinary Journal ISSN 1994-9057 (Print) ISSN 2070--0083 (Online), Volume 2 (4) September, 2008, Special Edition: Engineering.

[2]. Amit Rai, Dr. Y.P Joshi, "Applications and Properties of Fiber Reinforced Concrete”, IJERA, ISSN: 2248-9622, Vol. 4, Issue 5 (Version 1), May 2014.

[3]. Divyeshkumar D. Paradava1, Prof. Jayeshkumar Pitroda, "Utilization of Artificial Fibres in Construction Industry: A Critical Literature Review”, (IJETT) - Volume 4 Issue 10 - Oct 2013.

[4]. D. Jothi, "Application of Fiber Reinforcement Concrete Technique in Civil Constructions"

[5]. DOC: TX 34 (1145), "Textiles - Synthetic Fibers for reinforcement in concrete for use in construction works Specification", Bureau of Indian Standards, India.

[6]. Dr. Vagheesha S. Mathda, Ms. Hemali K. Khaire, "Study of Effects of Polyester Fibers on Compressive Strength of Concrete”, (IJRASET), Volume 4 Issue I, January 2016 IC Value: 13.98 ISSN: 2321-9653.

[7]. IS: 2386 (Part I) - 1963, "Methods of Test for Aggregates for Concrete-Part 1 Particle Size and Shape”, Bureau of Indian Standards, India.

[8]. S: 2386 (Part III) - 1963, "Methods of Test for Aggregates for Concrete Part 3 Specific Gravity, Density, Voids, Absorption, Bulking”, Bureau of Indian Standards, India.

[9]. IS: 516 - 1959, "Methods of Tests for Strength of Concrete”, Bureau of Indian Standards, India.

[10]. K. Murahari, Rama Mohan Rao P, "Effects of Polypropylene fibers on the strength properties Of fly ash based concrete”, International Journal of Engineering Science Invention ISSN (Online): 2319 - 6734, ISSN (Print): 2319 6726 www.ijesi.org Volume 2 Issue 5 May2013.

[11]. K. Vamshi Krishna, J. Venkateswara Rao, "Experimental study on behavior of fiber reinforced concrete for rigid pavements", IOSR Journal of Mechanical and Civil Engineering (IOSR-JMCE) e-ISSN: 2278-1684, p-ISSN: 2320334X, Volume 11, Issue 4 Ver. VII (Jul- Aug. 2014). 